UDC $347.1+347.61 / .64$

DOI https://doi.org/10.32849/2663-5313/2021.9.04

\title{
Mariia Lohvinova,
}

PhD in Law, Associate Professor, Leading Researcher, Academician F. H. Burchak Scientific Research Institute of Private Law and Entrepreneurship of National Academy of Law Sciences of Ukraine, 23a, Mykola Raevsky street, Kyiv, Ukraine, postal code 01042, mariialohvinova@gmail.com

ORCID: orcid.org/0000-0002-6416-3082

Scopus-Author ID: 57212405689

Lohvinova, Mariia (2021). System of principles of exercising subjective family rights. Entrepreneurship, Economy and Law, 9, 23-30, doi: https://doi.org/10.32849/2663-5313/2021.9.04

\section{SYSTEM OF PRINCIPLES OF EXERCISING SUBJECTIVE FAMILY RIGHTS}

Abstract. Purpose. This publication aims to investigate scientific and theoretical conceptual approaches to statutory consolidation and practical application of the principles of exercising subjective family rights. Research methods. The contribution is based on general scientific and special methods of scientific knowledge. Results. The author has analyzed main doctrinal approaches to understanding the general legal (general) principles of exercising subjective rights; interbranch (civil law) principles of exercising subjective rights (the principles of free disposition; justice, good faith and reasonableness; inadmissibility of abuse in exercising subjective rights; guaranteed smooth exercise of subjective rights); branch principles of family law (the principles of personal exercise of family rights; priority of interests of family and the child; equality in the exercise of family rights; freedom of a family law agreement) and institutional principles of exercising subjective family rights. It has been proved that the system of principles of exercising subjective family rights comprises a multilevel (hierarchical) structure. Conclusions. As a result of the study, the following system of principles of exercising subjective family rights has been proposed: 1) interbranch (civil law) principles of exercising subjective rights is applied in the subsidiary manner in the field of family law regulation, namely: the principles of free disposition; justice, good faith and reasonableness; inadmissibility of abuse in exercising subjective rights; guaranteed smooth exercise of subjective rights; 2) branch principles of family law towards exercising subjective family rights: the principles of personal exercise of family rights; priority of interests of family and the child; equality in the exercise of family rights; freedom of a family law agreement. At the same time, the author has justified the viewpoint that the branch principles of family law on the exercise of subjective family rights are independent in the system of legal principles.

Key words: principles of law, principles of exercising subjective rights, principles of exercising subjective family rights, family law, family legislation, civil law.

\section{Introduction}

V.P. Hrybanov initiated a detailed study of the system of principles of enforcement of rights. The scientist attributed the following fundamentals to the principles of exercising civil rights: legality, good faith, conformity of exercising the right with its purpose, the actuality of exercising subjective rights, cooperation in exercising subjective rights and performing legal duties, and economic efficiency (Hrybanov, 2001). Further scientific studies of the system of principles of exercising subjective rights, which were conducted by both civil law scholar - Ye.V. Vavylin, T.V. Deriuhina, O.O. Kot, M.O. Stefanchuk, Ye.O. Sukhanov, and Yu.V. Tsiukalo, and representatives of the science of family law - V.O. Kozhevnykova, M.A. Kondrashova, L.V. Krasytska, and M.V. Mendzhul, allow stating that the system of principles of exercising subjective family rights comprises a multilevel (hierarchical) structure. Moreover, O.O. Kot notes that exercising subjective civil rights is affected by three levels of principles: general legal, branch, and special (institutional) (Kot, 2017, p. 56), thus forming a three-level hierarchy for exercising subjective civil rights. At the same time, the analysis of contributions of the abovementioned scientists shows that a set of principles of exercising subjective family rights is a more complicated phenomenon which, in addition to general, branch, and institutional principles, also includes interbranch principles principles (fundamentals) of exercising subjective civil rights.

2. General legal (general) fundamentals of exercising subjective rights

General legal (general) fundamentals of exercising rights are top in the hierarchy 
of principles (fundamentals) of exercising rights. As for their specific list, the legal doctrine lacks a unified opinion in this context. Thus, a broad approach considers such general principles as universal categories, which are peculiar to any legal system as they reflect the best achievements of humankind and are generally recognized by international acts (Rabinovych, 2007; Skakun, 2010; Mendzhul, 2020). In the author's opinion, the above approach is too broad. Therefore, the author believes that the principles which are enshrined in the Constitution of Ukraine and have a profound influence on the legal system as a whole should be regarded as general legal (general) principles of exercising subjective rights. A comparison of relevant professional studies allows attributing the following general fundamentals (principles) to constitutional ones: legality, justice, freedom, humanism, and judicial protection of rights and legitimate interests (Pohrebniak, 2008; Skakun, 2010; Koziubra, 2015; Mendzhul, 2020).

3. Interbranch fundamentals of exercising subjective rights

Interbranch principles of exercising subjective rights are the relevant principles (fundamentals) of exercising subjective civil rights, as they 1) are general for the legal regulation of the entire system of private law relations; 2) are original towards family law principles (Krasytska, 2015; Vatras, 2020); 3) are applied in the subsidiary manner to regulate family law relations. Given the latter statement, V.O. Kozhevnykova treats the following principles as common to civil and family law: equality (equality of rights), property independence, the autonomy of the will, and contractual freedom (Kozhevnykova, 2013, pp. 40-42). M.V. Mendzhul also distinguishes a range of civil principles regulating family relations, namely: the principles of agreed (by agreement) regulation of relations between their parties, guaranteeing the secrecy of private life, the inadmissibility of arbitrary interference in private life (Mendzhul, 2020, pp. 93-94). Ye.O. Michurin, in his turn, highlights the principle of contractual freedom noticing that it is "not a fundamental defined by the Family Code of Ukraine but is fixed in the Civil Code of Ukraine and covers, in particular, an antenuptial agreement". At the same time, the scientist stresses that individual provisions for the agreement ("agreement form", "term of agreement", "alteration of agreement", "agreement termination", "invalidation of agreement") to be borrowed from civil law if provisions of a particular agreement between the parties in family law relations do not contradict the fundamentals of family (and civil) laws (Michurin, 2017, p. 113).
The study of research activities on the issue under consideration gives grounds to conclude that in terms of the most general approach, civil law principles (fundamentals) of exercising subjective civil rights are reduced to two basic pillars: discretionary nature and exercise of rights in good faith. Moreover, they "embrace" some "detailing" provisions. Thus, scientists attribute the following to the principle of free disposition: contractual freedom; the autonomy of the will of all participants in legal relations; state's non-interference in private law relations; independence and smooth exercising of rights. The elements of the principle of exercising rights in good faith are justice and reasonableness, the inadmissibility of abuse, the exercise of the right under its purpose, mutual respect, and cooperation of the parties in legal relations, etc. (Volkov, 2007; Vavylyn, 2009). Such a doctrinal separation of components of the principle of free disposition and exercise of rights in good faith allows identifying civil principles of exercising subjective rights, which have interbranch nature during the regulation of private law relations, as follows:

free disposition: Some scientists consider the principle of free disposition largely fundamental to the whole realm of private law (Vavylyn, 2009). At the same time, a free disposition is a complex and multifaceted category that is widely applied in legal doctrine without having its textual consolidation in the Civil Code. Although the principle of free disposition is not covered by art. 3 of $\mathrm{CC}$ among the fundamentals of civil law, N.S. Kuznietsova rejects doubts about its belonging to the latter (Kuznetsova, 2003, pp. 10-11).

Scientists express fairly diverse judgments about the essence of free disposition and its correlation with other legal principles. The author agrees with O.Ie. Kukhariev on the point that free disposition is based on the legal freedom of the subjects of legal relations, which: allows them to choose a behavioral pattern; allows them to determine the content of legal relations at their discretion, i.e., their rights and responsibilities; ensures a manifestation of the initiative of legal subjects, which encompasses the implementation of statutory freedom (Kukhariev, 2020, p. 12). It should be noted that O.O. Kot puts a similar content in such a principle of the exercise of subjective rights, which he defines as freedom to exercise subjective civil rights (the exercise of a subjective right depends solely on the will and discretion of a person) (Kot, 2017, pp.59-61);

- justice, good faith and reasonableness. Nowadays, the literature lacks a concurrent point of view on whether "justice", "good faith", and "reasonableness" should be considered as 
a single principle or whether they should be distinguished (Tobota, 2020, pp.38-39). At the same time, art. 3 of CC defines these categories as one of the fundamentals of civil law, which, in the author's opinion, primarily concerns the process of enforcement of rights. It is assumed that that this is one of the central ideas of civil law, which "permeates" the entire array of civil rules and regulates the conduct of subjects within any civil law institution. Its legal consolidation is an expected result of social development and is dictated by the need to build social relations (including between participants in legal relations) based on high moral and honest behavior of subjects (Tobota, 2020, pp.38-39). The issue of the content of "justice", "good faith", and "reasonableness" remains controversial, but, in general, these principles are evaluative categories which allow exceeding the scope of traditional "positive law" and determining the compliance of the conduct of subjects predominant in society with moral and ethical requirements in those cases when it is impossible to regulate a particular legal matter "exhaustively";

- inadmissibility of abuse in exercising subjective rights. In general, it is about a legal principle which, on the one hand, sets requirements for the exercise of any subjective right, and on the other - determines the permissible limits of enforcement. As noted in the literature, law principles are the working mechanisms that are used to determine the constraints of possible and acceptable conduct of the parties in legal relations (Kuznetsova, 2000, p. 123);

- guaranteed unimpeded exercise of subjective rights. Objective law cannot ensure a total absence of obstacles in exercising subjective rights, but it can vest the authorized person with legal guarantees for exercising his/her right (Kot, 2017, p. 80). E.V. Vavilin emphasizes the need to create a legal environment that would be favorable for the operation of the mechanism of exercise of subjective rights. (Vavylyn, 2009, p. 17). This is ensured by statutory consolidation of the provisions prohibiting unlawful interference in private law relations, eliminating obstacles for exercising subjective rights, the system of methods for protecting subjective rights, judicial and extrajudicial mechanisms of protection of the rights and legitimate interests of the individual, ensuring the actual implementation of legal obligations in relation to authorized subject by other participants in legal relations, effective human rights activities of courts and other law enforcement agencies, etc.

4. Branch fundamentals of exercising subjective family rights

As for the branch principles of family law in the context of exercising subjective rights, the author considers it expedient starting with an analysis of the legislative provisions of foreign states.

Thus, in the Family Code of the Republic of Moldova dated 26.10.2000 No1316-XIV, as well as in FC of Ukraine, an individual chapter 2 of section 1 deals with the issues of realization and protection of family rights. Rules of the code enshrine the provisions of equality within family relations, which comprises the availability of equal rights and responsibilities spouses (part 1 of art. 5); impossibility of assignment of family rights and responsibilities to third parties (part 2 of art. 5); exercise of family rights at one's discretion, unless otherwise provided by law (part 1 of art. 6); exercise of family rights and performance of family duties should not violate the rights and legitimate interests of other family members and third parties (part 2 of art.6); legal protection of family rights, except their implementation contrary to the purpose of the rights or the law (part 1 of art.7); judicial and extrajudicial protection of family rights (parts 2, 4 of art. 7); protection of family rights in the ways prescribed by law (part 3 of art. 7); non-application of limitation of legal claims to the requirements arising from family relations, unless otherwise provided by law (part 1-2 of art. 8).

In the Code on Marriage and Family of the Republic of Belarus as of 09.07.1999 No. 278-Z, there is no separate subsection on the exercise and protection of family rights, but section 1 "General Provisions" prescribes the following principles: guaranteeing legal protection of family rights if they are exercised under their purpose (part 1 of art. 5); exercise of rights arising from family and marital relations without violating the rights and legitimate interests of others (part 2 of art.5); judicial and extrajudicial protection of family rights (art. 6), and others. At the same time, one can note the availability of a provision according to which the state priority task in social policy is to protect marriage, family, and care of motherhood, fatherhood, and childhood (art. 3).

The peculiarity of Georgian legislation is that family relations are regulated by the Civil Code. However, Book 5 "Family Law" of CC of Georgia as of July 26, 1997, No. 786-IIc does not contain general provisions of family law and does not fix a systematized list of basic principles for the exercise and protection of family rights.

Family relations in Romania and the Czech Republic are also regulated by the civil codes. At the same time, Book 2 "On Family" of CC of Romania as of July 17, 2009 and Part 2 "Family Law" of C Cof the Czech Republic as of 03.02.2012 do not contain general provisions of family law. 
A similar situation occurs in Polish law. Despite the availability of an independent source of family law - the Family and Guardianship Code of the Republic of Poland as of 25.02.1964, there is no rule on the regulation of family relations.

It can be said that not all foreign countries enshrined in law the general fundamentals (principles) of exercising family rights (fulfillment of family obligations). At the same time, their presence is evidence of a sufficiently detailed approach to the statement of the general provisions of family law as the regulatory framework of an independent branch of law, which is inherent in the latest family codes.

Therefore, the study of scientific publications, a comparative examination of national and foreign laws allows identifying the following branch principles of subjective family rights:

- the principle of personal exercise of family rights. As defined in Part 1 of art.14 of the Family Code, family rights are closely related to a person and as such may not be transferred to another person. Part 2 of this article includes exceptions to the rule: the rights of a child or a person whose legal capacity is limited are exercised by their legal representatives (or they provide relevant assistance in exercising).

Based on data found in literature, it is concluded that family rights are exercised independently by the person endowed with them (Kozhevnykova, 2019, p. 210) and cannot be transferred to other subjects on basis of an arrangement (Dutko, 2013, p. 136). In general, the author agrees with the above, as family rights are mostly of personal and non-monetary nature and therefore cannot be alienated or delegated. At the same time, FC contains norms which, in the case of relevant conditions or valid reasons, allow exercising some family rights procedurally (the author's) by proxy (e.g., submission of an application for marriage registration to the Registry Office) (part 3 of art.28 of FC), and norms which strongly prohibit the participation of a representative in the exercise of family rights (art. 34, art. 223 of FC). Thus, it should be borne in mind that this rule is not absolute and, in some cases, it is permissible to exercise some family rights (primarily property ones) by proxy provided that it does not contradict the law and legal relations;

- the principle of priority of family and child interests. This principle appears from some provisions of the Family Code. Therefore, one of the tasks of family laws is to promote the family as a social institution and a union of individuals (part 2 of art.1); the State protects the family, childhood and creates conditions for the strengthening of the family (part 1 of art. 5); regulation of family relations should be carried out with utmost consideration of the best interests of a child and family members with disabilities (part 8 of art. 7); parental rights cannot be exercised against the interests of the child (part 2 of art. 155.) According to art. 11 of the Law of Ukraine "On Protection of Childhood", the subject of the main concern and the main duty of parents is to ensure the interests of their child.

The above fundamental (principle) is also found in case law. The judgments of the European Court of Human Rights have repeatedly stated that the children's interests might be opposed to those of their parents (Olsson v Sweden (No. 2) dated 27.11.1992 p., Series A, No. 250, arts. 35-36, § 90), and special attention should be paid to the most important interests of the child, which by their importance and nature should prevail over the interests of parents (Hunt v. Ukraine dated 07.12.2006, No. 31111/04, § 54).

The judgments of the Supreme Court regularly emphasize that the rights of parents in relation to the child are derived from the rights of the child to the harmonious development and proper upbringing; the cases involving a child must, first of all, determine and take into account the interests of the child, according to objective circumstances of the dispute, and then - the rights of the parents (resolutions as of 24.04.2019 in the case No. 300/908/17 (proceedings No. 61-44369sv18); as of 06.06.2019 in the case No. 495/2106/17 (proceedings No. 61-592sv19); as of 30.03.2021 in the case No. 542/1428/18 (proceedings No. 61-18612sv19). Even in case of any legal conflict, incompleteness, vagueness, or contradiction of the legislation which regulates controversial legal relations concerning the interests of the child, taking into account provisions of art. 3 of the Convention on the Rights of the Child, priority should be given to the best interests of the child (Judgement of the Supreme Court as of 14.05.2021 in case No. 548/2434/19 (proceedings No. 61-2090sv21).

In general, the author believes that the priority of family and child interests should be decisive in addressing the availability or lack of abuse of rights in exercising subjective family rights;

- the principle of equality in exercising family rights. This pillar is a logical extension of the general principle of legal equality of participants in public relations, which is notedly peculiar to the regulation of private law relations and follows from some provisions of $\mathrm{FC}$ : women and men enjoy equal rights and assume equal responsibilities in family relations, marriage, and family (part 6 of art.7); the mother and the father assume equal rights and responsibilities in respect of the child irrespectively of whether they were married to each other or 
not (part 1 of art. 141; part 3 of art. 11 of the Law of Ukraine "On Protection of Childhood"); children have equal rights and responsibilities towards their parents regardless of whether their parents were married to each other (art. 142), including, towards equal upbringing by parents, etc.

The importance of distinguishing this fundamental as a principle of exercising subjective family rights is to root out stereotypes that still prevail in the public consciousness and determine the actual impact on the practice of legal regulation through the unreasonable provision of "benefits" to individual subjects of family relations ("husband" - the head of the family, who must ensure its maintenance and has a "deciding vote" in resolving issues of family life; "a minor child must live with his mother"; "the older child has "more rights" to the property of the parents", etc.).

In this context, it is essential to emphasize that Parliamentary Assembly Resolution No. 2079 (2015) "Equality and shared parental responsibility: the role of fathers" highlights the importance "to transcend gender stereotypes about the roles supposedly assigned to women and men within the family and is a reflection of the sociological changes that have taken place over the past fifty years in terms of how the private and family sphere is organized".

The judgments of the European Court of Human Rights have repeatedly paid attention to the equality of parents' rights in disputes over child custody and the waiver of any gender-based presumptions (Judgements in the case of Sommerfeld v. Germany dated 08.07.2003, Zaunegger v. Germany dated 03.12.2009). Moreover, Judge Carlo Ranzoni representing the Principality of Liechtenstein expressed his opinion in the case "M.S. v. Ukraine" (judgement dated 11.10.2017) focusing on "an important and controversial issue peculiar to Ukraine - the "presumption in favor of the mother" in matters of child care". The judge noted that such a presumption is not confirmed at the UN level, does not emerge from the Declaration or case law of the European Court, and does not correspond to the policy of the Council of Europe and most member states of the Council of Europe. "Due to the presumption in favor of the mother, national courts reduced the scope of their assessment limited themselves to the identification of the absence of "exceptional circumstances", and refused to examine further circumstances that would be decisive in guaranteeing the best interests of the child" (Lohvinova, 2017, p. 127).

As of today, it should be noted that national courts follow the principle of equal rights of parents in the upbringing of a child while dealing with family disputes. Thus, the Supreme Court is strongly focused on protecting the rights and interests of mother and father as equal participants in family relations and avoids discriminatory treatment or humiliation of the father's role in its judgments. At the same time, the Supreme Court notes that regulations on equal rights and responsibilities of parents in the upbringing of a child cannot be interpreted to the detriment of the interests of the child. When deciding on cases of determining of a child's place of residence, establishing the procedure for participation in the upbringing of the child, granting permission for a minor child to travel abroad without the consent of the father, the courts must principally protect the rights and interests of the child by identifying what best suits his/her interests"; "equality of parents' rights in relation to the child is derived from the child's rights and interests for the harmonious development and decent upbringing" (Resolution as of 04.07 .2018 in the case No. 712/10623/17 (proceedings No. 14-244tss18); as of 17.10 .2018 in the case No. 402/428/16- ц (proceedings No. 14-327 цс18); as of 18.03.2019 in the case No. 215/4452/16-ц (proceedings No. 61-1145св19); as of 20.05.2021 in the case No. 686/27095/19 (proceedings No. 61-2826св21);

- the principle of freedom of a family law agreement. As noted in the literature, a characteristic feature of private law is that each of its branches has its own tool of the dispositive method of regulation; accordingly, a family law (family) agreement performs these functions within family law (Kyslova, Kokhtenko, 2019, p. 39). Family law agreements should be understood as agreements concluded by individuals and aimed at establishing, modifying, or terminating family rights and responsibilities (Kharytonov, 2006, p. 54).

The principle of freedom of a family law agreement in exercising subjective family rights is primarily realized in the provisions of part 2 of art.7 of FC according to which family relations can be settled by arrangement (agreement) between their participants. The regulation of family relations by arrangement (agreement) of the parties is also stipulated by art. 9 of FC: subjects of family law can regulate their relations by arrangement (agreement), if it does not contradict statutory requirements and the moral principles of society (part 1).

5. Institutional fundamentals of exercising subjective family rights

The distinguishing of institutional principles of exercising subjective family rights as the lowest link in the hierarchical system of principles of exercising subjective family rights is an individual and rather controversial 
issue. Thus, M.V. Mendzhul marks the option of identifying special principles which are the basis for regulating homogeneous family relations. For example, the institution of marriage is based on the principles of monogamy, voluntary marriage, and freedom of divorce (Mendzhul, 2020, p. 92) The scholar justifies her standpoint by referring to the legal doctrine of the Czech Republic, where the principles of family law are divided into general (the principle of child welfare, the principle of solidarity (mutual assistance), the principle of equality) and the principles which concern some types of family law relations (principle of enhanced protection of marriage and parenthood, principle of monogamy, principle of voluntary marriage, principle of freedom of divorce, principle of equality of men and women in marriage, equality of children born in and out of wedlock) (Mendzhul, 2020, p. 60). In addition to general family principles, N.S. Sherstnieva also highlights the institutional principles of family law by dividing them into: priority (providing priority protection of the rights and interests of minors; priority of family upbringing of children, care for their welfare), mutual (the principle of the voluntary marriage of man and woman; equality of marital rights in the family; settlement of intra-family issues by mutual consent; enforcement of the rights and interests of family members with disabilities) and values (ensuring quality of life, the safety of family, motherhood, fatherhood, and childhood) (Sherstneva, 2007, pp. 12-13).

Therefore, in terms of the doctrine, there are all grounds for distinguishing institutional principles for exercising subjective family rights (e.g., the principle of priority of family upbringing of the child (part 3 of art. 5 of FC) or the principle of a joint exercise of parental rights (part 1 of art. 157 of FC). In the context of their specific list (system), it is the subject of specialized research on the exercise of individual types of subjective family rights.

\section{Conclusions}

Based on the analysis of scientific publications, comparative study of the rules of civil and family law, foreign law, as well as case law, the author believes that the system of principles of exercising subjective family rights comprises:

1) interbranch (civil) principles of exercising subjective rights, which are applied in a subsidiary manner in family law regulation, namely: the principles of free disposition; justice, good faith and reasonableness; inadmissibility of abuse in the exercise of subjective rights; guaranteed smooth exercise of subjective rights);

2) branch principles of family law for exercising subjective family rights, namely: the principles of personal exercise of family rights (part 1 of art. 14 of FC); priority of family and child interests (part 2 of art. 1, part 1 of art. 5, part 8 of art. 7 and part 2 of art. 155 of FC); equality in the exercise of family rights (part 6 of art. 7 , part 1 of art. 141, part 1 of art. 142 of FC, etc.); freedom of a family law agreement (part 2 of art. 7 of FC, art. 9 of FC).

At the same time, the author holds that the branch principles of family law for exercising subjective family rights are independent in the system of legal principles, as they are derived from common law principles, interbranch principles of private law and branch principles of family law, reflect features and specify legal regulation of relations towards exercise (implementation) of subjective family rights.

\section{References:}

Codul civil al Românieidin (2009). (actualizat pânăla data de 4.02.2016). [Romanian Civil Code], Retrieved September 11, 2021, from http://legislatie.just.ro/Public/DetaliiDocument/175630 (in Romanian)

Dutko, A.O. (2013). Dohovir yak rehuliator simeinykh vidnosyn: osoblyvosti konstruktsii [Contract as a regulator of family relations: design features], Scientific bulletin of Lviv State University of Internal Affairs. Legal series, 2013, no.3, pp. 135-142 (in Ukrainian).

Hrazhdanskyi kodeks Cheshskoi respublyky (2012). [The civil code of the Czech republic], Retrieved September 11, 2021, from http://anesro.com/downl/zakon/89-2012 Sb.pdf (in Russian).

Hrazhdanskyi kodeks Hruzyy (1997). [The civil code of Georgia], Retrieved September 11, 2021, from https://matsne.gov.ge/ru/document/download/31702/75/ru/pdf (in Russian).

Hrybanov, V.P. (2001). Osushchestvlenye y zashchyta hrazhdanskykh prav [Realization and protection of the civil rights]. Moskva : Statut (in Russian).

Kharytonov, Ye.O. et al. (2006). Naukovo-praktychnyi komentar do Simeinoho kodeksu Ukrainy [Scientific and practical commentary on the Family Code of Ukraine]. Kharkiv : TOV «Odisei» (in Ukrainian).

Kodeks Respublyky Belarus o brake y seme (1999). [The code of Byelorussia about marriage and family], Retrieved September 11, 2021, from https://online.zakon.kz/Document/?doc id $=30414964 \#$ pos $=5 ;-116$ (in Russian).

Kodeks rodzinny i opiekuńczy (1964). [Family and guardianship code], Retrieved September 11, 2021, from https://isap.sejm.gov.pl/isap.nsf/DocDetails.xsp?id=wdu19640090059 (in Polish). 
Kot, O.O. (2017). Problemy zdiisnennia ta zakhystu subiektyvnykh tsyvilnykh prav: dys. ... d-ra yuryd. nauk ...12.00.03 [Problems of exercise and protection of subjective civil rights: dis....doctor of juridical sciences ...12.00.03]. The Academician F. H. Burchak Scientific-Research Institute of Private Law and Entrepreneurship of National Academy of Law Sciences of Ukraine. Kyiv (in Ukrainian).

Kozhevnykova, V.O. (2013). Pryntsypy tsyvilnoho ta simeinoho prava: porivnialno-pravovyi aspekt [Principles of Civil and Family Law: Comparative and Legal Aspect], Scientific Bulletin of the International Humanities University. Series: Jurisprudence, 2013, no. 6-1, pp. 39-43 (in Ukrainian).

Kozhevnykova, V.O. (2019). Naukovo-teoretychni zasady obmezhennia prav subiektiv simeinykh vidnosyn: dys. ... d-ra yuryd. nauk ...12.00.03 [Scientific and Theoretical Principles of the Restriction of Rights of Subjects of Family Relations: dis. ... doctor of juridical sciences ...12.00.03]. Western Ukrainian National University. Ternopil (in Ukrainian).

Koziubra M.I. et al. (2015). Zahalna teoriia prava: pidruchnyk [General theory of law: a textbook]. Kyiv : Vaite (in Ukrainian).

Krasytska, L.V. (2015). Problemy zdiisnennia ta zakhystu osobystykh ta mainovykh prav batkiv $i$ ditei: dys. ... d-ra yuryd. nauk ...12.00.03 [Problems of Execution and Protection of the Personal and Property Rights of Parents and Children: dis. ... doctor of juridical sciences ...12.00.03]. National Prosecution Academy of Ukraine. Kyiv (in Ukrainian).

Kukhariev, O.Ye. (2020). Dyspozytyvnist v spadkovomu pravi: avtoref. dys. ... d-ra yuryd. nauk ...12.00.03 [Discretion within Inheritance Law: dis. abstract doctor of juridical sciences ... 12.00.03]. Kharkiv National University of Internal Affairs. Kharkiv (in Ukrainian).

Kuznetsova, N.S. (2003). Pryntsypy suchasnoho zoboviazalnoho prava Ukrainy [Principles of Modern Binding Law of Ukraine], Ukrainian commercial law, 2003, no.4, pp. 9-15 (in Ukrainian).

Kuznetsova, N.S. et al. (2000). Osnovni zavdannia knyhy pershoi proektu Tsyvilnoho kodeksu Ukrainy [The main objectives of the book of the first draft Civil Code of Ukraine]. Kodyfikatsiia pryvatnoho (tsyvilnoho) prava Ukrainy [Codification of private (civil) law of Ukraine]. Kyiv : Ukr. tsentr prav. studii (in Ukrainian).

Kyselova, O.I., Kokhtenko, R.V. (2019). Simeino-pravovi dohovory ta yikh rol u vrehuliuvanni simeinykh sporiv [Family law contracts and their role in resolving family disputes], Legal Horizons, 2019, no. 17 (30), pp. 37-41 (in Ukrainian).

Lohvinova, M.V. (2017). Diialnist Yevropeiskoho sudu z prav liudyny v sferi zakhystu simeinykh prav ta okhoroniuvanykh zakonom interesiv u konteksti pravozastosovchoi praktyky Ukrainy [Activities of the European Court of Human Rights in the field of protection of family rights and legally protected interests in the context of law enforcement practice of Ukraine]. Pravovi pozytsii Yevropeiskoho sudu z prav liudyny u pravozastosovnii praktytsi Ukrainy: zb. nauk. pr. [Legal positions of the European Court of Human Rights in the law enforcement practice of Ukraine]. Ivano-Frankivsk : Suprun V.P., pp. 93-132 (in Ukrainian).

Mendzhul, M.V. (2020). Teoretychni problemy dii pryntsypiv simeinoho prava: dys. ... $d$-ra yuryd. nauk ...12.00.03 [Theoretical problems of the actionof family law principles: dis. ... doctor of juridical sciences ... 12.00.03]. Uzhgorod National University of the Ministry of Education and Science of Ukraine, Kharkiv National University of the Ministry of Education and Science of Ukraine. Kharkiv (in Ukrainian).

Michurin, Ye.O. (2017). Tsyvilistyka v suchasnii yurysprudentsii [Civicsin the Contemporary Jurisprudence], Journal of the National Academy of Legal Sciences of Ukraine, 2017, no. 2 (89), pp. 110-119 (in Ukrainian).

Pohrebniak, S.P. (2008). Osnovopolozhni pryntsypy prava (zmistovna kharakterystyka) [Fundamental principles of law (meaningful characteristic)]. Kharkiv (in Ukrainian).

Rabinovych, P.M. (2007). Osnovy zahalnoi teorii prava ta derzhavy : navch. posib. [Fundamentals of the general theory of law and the state : tutorial]. Lviv : Krai (in Ukrainian).

Semeinyi kodeks Respublyky Moldova (2000). [Family Code of the Republic of Moldova], Retrieved September 11, 2021, from http://continent-online.com/Document/?doc_id=30398164 (in Russian).

Sherstneva, N.S. (2007). Pryntsypy rossyiskoho semeinoho prava: avtoref. dys. ... d-ra yuryd. nauk ...12.00.03 [Principles of the Russian family right : dis. abstract doctor of juridical sciences ...12.00.03]. The Russian Academy of Public Administration under the President of the Russian Federation. Moskva (in Russian).

Skakun, O.F. (2010). Teoriia derzhavy i prava : pidruchnyk [The theory of state and law : a textbook]. Kyiv: Alerta; KNT; TsUL (in Ukrainian). 
Tobota, Yu.A. (2020). Pryntsyp spravedlyvosti, dobrosovisnosti i rozumnosti u tsyvilnomu pravi [The principle of justice, good faith and reasonableness in civil law]. Kharkiv (in Ukrainian).

Vatras, V.A. (2020). Dzherela simeinoho prava : dys. ... d-ra yuryd. nauk ...12.00.03 [Sources of Family Law: dis. ... doctor of juridical sciences ...12.00.03]. Leonid Yuzkov Khmelnytsky University of Management and Law, Western Ukrainian National University. Ternopil (in Ukrainian).

Vavylyn, E.V. (2009). Mekhanyzm osushchestolenyiay zashchyth razhdanskykh prav: dys. ... d-ray uryd. nauk ...12.00.03 [The mechanism of realization and protection of thecivil rights : dis. ... doctor of juridical sciences ...12.00.03]. The Russian Academy of Public Administration under the President of the Russian Federation. Moskva (in Russian).

Volkov, A.V. (2007). Teoryia kontseptsyy zloupotreblenyia hrazhdanskymy pravamy [The theory of the concept of abuse by the civil rights]. Volhohrad : Stanytsa (in Russian).

\section{Марія Логвінова,}

кандидат юридичних наук, доцент, провідний науковий співробітник, Науково-дослідний інститут приватного права і підприємництва імені академіка Ф. Г. Бурчака Національної академії правових наук України, вулиия Раєвського, 23-а, Киї, Украйна, індекс 01042, mariialohvinova@gmail.com

ORCID: orcid.org/0000-0002-6416-3082

Scopus-Author ID: 57212405689

\section{СИСТЕМА ПРИНЦИПІВ ЗДІЙСНЕННЯ СУБ'ЄКТИВНИХ СІМЕЙНИХ ПРАВ}

Анотація. Мета. Запропонована публікація має на меті дослідити науково-теоретичні концептуальні підходи до нормативного закріплення та практичного застосування принципів здійснення суб'єктивних сімейних прав. Методи дослідження. Роботу виконано на підставі загальнонаукових і спеціальних методів наукового пізнання. Результати. Проаналізовано основні доктринальні підходи до розуміння загальноправових (загальних) засад здійснення суб'єктивних прав; міжгалузевих (цивілістичних) засад здійснення суб'єктивних прав (принципів диспозитивності, справедливості, добросовісності й розумності, недопустимості зловживання під час здійснення суб'єктивних прав, гарантованого безперешкодного здійснення суб'єктивних прав); галузевих засад сімейного права (принципів особистого здійснення сімейних прав, пріоритетності інтересів сім'ї та дитини, рівності під час здійснення сімейних прав, свободи сімейно-правового договору) та інституційних засад здійснення суб'єктивних сімейних прав. Доведено, що система принципів здійснення суб'єктивних сімейних прав являє собою багаторівневу (ієрархічну) структуру. Висновки. У результаті дослідження констатовано, що систему принципів здійснення суб'єктивних сімейних прав становлять, по-перше, міжгалузеві (цивілістичні) принципи здійснення суб'єктивних прав, що в субсидіарному порядку застосовуються у сфері сімейно-правового регулювання (зокрема, принцип диспозитивності, принцип справедливості, добросовісності й розумності, принцип недопустимості зловживання під час здійснення суб'єктивних прав, принцип гарантованого безперешкодного здійснення суб'єктивних прав); по-друге, галузеві принципи сімейного права щодо здійснення суб'єктивних сімейних прав (зокрема, принцип особистого здійснення сімейних прав, принцип пріоритетності інтересів сім'ї й дитини, принцип рівності під час здійснення сімейних прав, принцип свободи сімейно-правового договору). При цьому обгрунтовується позиція, що галузеві принципи сімейного права щодо здійснення суб'єктивних сімейних прав посідають самостійне місце в системі правових принципів.

Ключові слова: принципи права, принципи здійснення суб'єктивних прав, принципи здійснення суб’єктивних сімейних прав, сімейне право, сімейне законодавство, цивільне право.

The article was submitted 14.09.2021

The article was revised 05.10.2021

The article was accepted 26.10.2021 